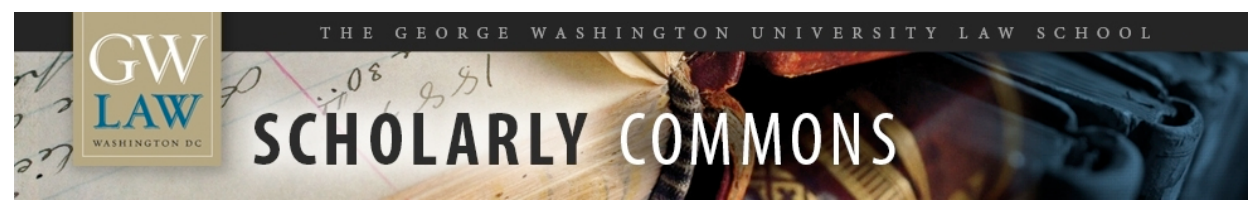

GW Law Faculty Publications \& Other Works

Provisional Application of Treaties and Other Topics: The SeventySecond Session of the International Law Commission

Sean D. Murphy

Follow this and additional works at: https://scholarship.law.gwu.edu/faculty_publications

Part of the Law Commons 


\title{
PROVISIONAL APPLICATION OF TREATIES AND OTHER TOPICS: THE SEVENTY-SECOND SESSION OF THE INTERNATIONAL LAW COMMISSION
}

\author{
Forthcoming in 115 American Journal of International Law (2021) \\ By Sean D. Murphy*
}

The International Law Commission (ILC) held its seventy-second session from April 26 to June 4 and from July 5 to August 6, 2021 in Geneva, under the chairmanship of Mahmoud Hmoud (Jordan). ${ }^{1}$ This session was originally scheduled for the summer of 2020 , but had to be postponed due to the outbreak of the COVID-19 pandemic. ${ }^{2}$ The pandemic continued in 2021 to present health risks and travel difficulties for certain members; consequently, the Commission for the first time in its history held its session in a hybrid manner, with many members physically present in Geneva, while others participated online by means of Zoom. That approach required certain adjustments to the Commission's methods of work, but allowed the Commission to move forward in addressing the several topics on its current program of work.

Specifically, the Commission completed the second reading of two topics: provisional application of treaties; and protection of the atmosphere. Progress was also made in developing draft articles on immunity of state officials from foreign criminal jurisdiction, draft articles on succession of states with respect to state responsibility, and draft conclusions on general principles of law. Additionally, the Commission convened a study group on sea-level rise in relation to international law, which focused its work during this session on matters relating to the law of the sea. The Commission also added a topic to its long-term work program on subsidiary means for the determination of rules of international law, and elected a new member to fill a casual vacancy.

\section{HYBRID PROCEEDINGS}

For the first time since the Commission commenced its work in 1949, its session was held in a hybrid fashion, so that members could participate both in-person and online (the latter facing health risks and travel difficulties due to the ongoing COVID-19 pandemic). ${ }^{3}$ For those members present in Geneva, a larger room than usual was used to allow for social distancing, all members wore face masks unless speaking, and members could not be accompanied by any assistants during the first half of the session. Meeting times were compressed for most of the session and coffee breaks were eliminated. The Swiss government assisted the Commission by providing certain exemptions from its rules, which allowed members more easily to travel to and work in Geneva.

* Manatt/Ahn Professor of International Law, George Washington University, and member of the UN International Law Commission.

${ }^{1}$ See Report of the International Law Commission on the Work of Its Seventy-Second Session, UN GAOR, 76th Sess., Supp. No. 10, at 1-2, paras. 1, 4, UN Doc. A/76/10 (2021 advance version) [hereinafter 2021 Report]. the final version of the 2021 report will be available by September 2021. This report and other International Law Commission documents are available online at http://legal.un.org/ilc. In addition, UN documents are generally available online at https://documents.un.org/prod/ods.nsf/home.xsp.

${ }^{2}$ See Sean D. Murphy, Effects of the COVID-19 Pandemic on the Work of the International Law Commission, 114 AJIL 726 (2020) [hereinafter Murphy, Effects of the COVID-19 Pandemic].

${ }^{3}$ For a summary of the hybrid format, see 2121 Report, supra note 1, at 204-205, paras. 313-16. 
Given the hybrid format, certain special procedures and working methods were agreed exceptionally. To accommodate those members participating online from the Americas, Commission meetings in the morning were limited in principle to "non-interactive" presentations by members before the plenary (recommended to last no more than twenty minutes), which were recorded and could be watched (or read) at a time convenient for members located around the world. By contrast, afternoon sessions were "interactive," consisting mainly of either the adoption of decisions by the plenary or the work of the drafting committee. To participate in these interactive meetings online, some members had to work very early or very late in the day depending on their location. The online platform used by the Commission was Zoom, and members wishing to speak could literally raise their hand (if the member was in Geneva) or could electronically do so (if the member was participating online). In order to save time, "informal consultations" (chaired by special rapporteurs) took place during parts of some mornings that would otherwise have been unused.

Overall, the difficulties presented by the pandemic resulted in the Commission making much greater use of electronic means for distribution of materials to members and their assistants. Even members located in Geneva had to rely on such means given pandemic-related restrictions at the Palais des Nations (where the Commission met) on the distribution of paper. Of particular interest was the use in the drafting committee of electronic screens for displaying proposed textual changes by the special rapporteurs or members, which were intended to allow members in-person or remote to follow the proposals more easily.

It is possible that the use of such technologies will accelerate to some extent the improvements that the Commission was already making in its methods of work. At the same time, it is unlikely that remote participation by members will continue once the pandemic subsides; in any event, in-person interactions are likely viewed as optimal for members to identify and bridge the gaps among differing views.

\section{PROVISIONAL APPLICATION OF TREATIES}

The Commission completed the second reading of the topic provisional application of treaties, ${ }^{4}$ based on a sixth report by the special rapporteur, Juan Manuel Gómez-Robledo (Mexico) ${ }^{5}$

\footnotetext{
${ }^{4}$ For the text of the draft guidelines, see id. at 62-64; for the draft annex, see id. at 64-78; for the guidelines with commentary, see id. at 78-99; for a bibliography, see id. at 99-107.

${ }^{5}$ International Law Commission, Sixth Report on the Provisional Application of Treaties, UN Doc. A/CN.4/738 (Feb. 24, 2020) (prepared by Special Rapporteur Juan Manuel Gómez-Robledo) [hereinafter Sixth Report on Provisional Application of Treaties]. For discussion of prior work on these draft guidelines, see Sean D. Murphy, The Expulsion of Aliens and Other Topics: The Sixty-Fourth Session of the International Law Commission, 107 AJIL 164, 171-73 (2013) [hereinafter Murphy, Sixty-Fourth Session]; Sean D. Murphy, Immunity Ratione Personae of Foreign Government Officials and Other Topics: The Sixty-Fifth Session of the International Law Commission, 108 AJIL 41, 53-54 (2014) [hereinafter Murphy, Sixty-Fifth Session]; Sean D. Murphy, The Expulsion of Aliens (Revisited) and Other Topics: The Sixty-Sixth Session of the International Law Commission, 109 AJIL 125, 143-44 (2015) [hereinafter Murphy, Sixty-Sixth Session]; Sean D. Murphy, Identification of Customary International Law and Other Topics: The Sixty-Seventh Session of the International Law Commission, 109 AJIL 822, 822-32 (2015) [hereinafter Murphy, Sixty-Seventh Session]; Sean D. Murphy, Protection of Persons in the Event of Disasters and Other Topics: The Sixty-Eighth Session of the International Law Commission, 110 AJIL 718, 742-45 (2016) [hereinafter Murphy, Sixty-Eighth Session]; Sean D. Murphy,
} 
and on comments received from governments and international organizations regarding the text and commentary adopted at first reading in $2018 .^{6}$ The outcome of this topic is twelve draft guidelines with commentary, as well as a draft annex, collectively referred to as the Guide to Provisional Application of Treaties.

While changes were made to the first reading text, they were relatively modest. Whereas the first reading text was silent in draft guideline 1 as to the actors engaged in provisional application of treaties, the final text refers to such application "by States and international organizations." Draft guideline 4 on "Form of agreement" retains the basic elements identified in the first reading, albeit somewhat reformulated. It acknowledges in an opening clause that a treaty that is being applied provisionally might itself address provisional application, and further that such agreement may be in a separate treaty, but the draft guideline then goes on to elaborate other ways that an agreement on provisional application may be formed by other "means or arrangements," including through a resolution adopted at an international organization, or through a declaration by a state that is accepted by the other states (or international organizations) concerned. ${ }^{8}$ While the draft guideline may be helpful to states and international organizations by identifying these more exotic forms, it may be considered somewhat unbalanced; virtually all agreements on provisional application may be found in the treaty itself that is being provisionally applied or in a side agreement; very few (if any) examples may be found of provisional application in the form of a resolution adopted at an international organization or by a declaration of a state accepted by others. ${ }^{9}$

Crimes against Humanity and Other Topics: The Sixty-Ninth Session of the International Law Commission, 111 AJIL 970, 978-80 (2017) [hereinafter Murphy, Sixty-Ninth Session]; Sean D. Murphy, Anniversary Commemoration and Work of the International Law Commission's Seventieth Session, 113 AJIL 90, 97-100 (2019) [hereinafter Murphy, Seventieth Session]; Sean D. Murphy, Peremptory Norms of General International Law (Jus Cogens) and Other Topics: The Seventy-First Session of the International Law Commission, 114 American Journal of International Law 68, 85 (2020) [hereinafter Murphy, Seventy-First Session].

${ }^{6}$ Provisional application of treaties: Comments and observations received from Governments and international organizations, UN Doc. A/CN.4/737 (Feb. 14, 2020).

72121 Report, supra note 1, at 62 (guideline 1).

${ }^{8}$ Id. at 62 (guideline 4).

${ }^{9}$ For the Commission's commentary on international organization resolutions, see id. at 87, para. (6); for the commentary on the "exceptional possibility" of a state's declaration that is "expressly accepted" by other states, see $i d$. at 87-88, para. (7). With respect to the latter form, the special rapporteur pointed in his second and third reports to Syria's declaration accepting provisional application of the Convention on the Prohibition of the Development, Production, Stockpiling and Use of Chemical Weapons and on Their Destruction (CWC) prior to Syria's accession to that treaty. The circumstances of that incident, however, might be best understood as involving a unilateral declaration by Syria that established a legal obligation upon it, rather than an agreement on provisional application reached between Syria and all CWC states parties (which would have established rights and obligations for all the states concerned), given that there was no express acceptance by such states. See generally Marie Jacobsson, Syria and the Issue of Chemical Weapons: A Snapshot of a Legal Time Frame: The United Nations Security Council Resolution (2118) and the OPCW Executive Council Decision, in INTERNATIONAL LAW AND CHANGING PERCEPTIONS OF SECURITY: LIBER AMICORUM SAID MAHMOUdI 134 (Jonas Ebbesson, Marie Jacobsson, Mark Klamberg, David Langlet \& Pål Wrange eds., 2014). In any event, the Commission's commentary is neutral as to how best to understand the Syrian incident, simply indicating that it is "an example" of a state making a unilateral declaration about provisional application, see 2121 Report, supra note 1, at 62, n. 278, without resolving whether that declaration thereafter fell within the legal regime of provisional application or, alternatively, fell within the legal regime of unilateral declarations of states creating legal obligations. On the latter possibility, see Guiding Principles Applicable to Unilateral Declarations of States Capable of Creating Legal Obligations, YEARBOOK OF THE INTERNATIONAL LAW COMMISSION, vol. I, pt. II, at 161 (2006). 
Perhaps the most important draft guideline remains draft guideline 6, on "legal effect," which was reformulated somewhat to read:

The provisional application of a treaty or a part of a treaty produces a legally binding obligation to apply the treaty or a part thereof between the States or international organizations concerned, except to the extent that the treaty otherwise provides or it is otherwise agreed. Such treaty or part of a treaty that is being applied provisionally must be performed in good faith. ${ }^{10}$

The principal changes to the text of draft guideline 6 involved dropping of the phrase "as if the treaty were in force" before "between the States," which was viewed both as unnecessary and as creating confusion with the treaty's actual entry into force, and the addition of the second sentence on good faith. That sentence did not exist at first reading, but was viewed by the Commission as a second type of legal effect arising from an agreement on provisional application, inspired by article 26 of the Vienna Convention on the Law of Treaties (VCLT). ${ }^{11}$

One theme of the ILC's work on this topic concerned to what extent the rules of the VCLT should be seen as generally applicable to provisional application. Some members viewed many, if not most, of the VCLT rules as applicable or potentially applicable, while others viewed provisional application of treaties as a sui generis situation, where on the basis of existing practice only relatively few rules present in the VCLT could be viewed as relevant (for example, while the rule on pacta sunt servanda applies to an agreement on provisional application, the elaborate VCLT rules on termination and suspension of that agreement may not apply). This debate played out to a degree in draft guideline 7 on "reservations," where the first reading text contained two paragraphs asserting that the VCLT's rules on reservations applied mutatis mutandis to provisional application of treaties. Criticism by states and others that there existed no discernible practice supporting the ILC's position resulted in much more modest second reading text: "The present draft guidelines are without prejudice to any question concerning reservations relating to the provisional application of a treaty or a part of a treaty." 12

A similar shift occurred with respect to draft guideline 9. Its first two paragraphs indicate two ways that termination may occur: upon entry into force of the treaty between the states or international organizations concerned; and - unless it is otherwise agreed - upon notification by a state (or international organization) of its intention not to become a party,. ${ }^{13}$ Those paragraphs reflect the text of the VCLT on provisional application. ${ }^{14} \mathrm{~A}$ third paragraph as formulated at first reading provided that the draft guideline was "without prejudice to the application, mutatis mutandis, of the relevant rules set forth in part V, section 3," of the VCLT. That "without prejudice" clause was transformed at second reading so as to avoid any reference to the detailed termination and suspension rules of the VCLT. Instead, the relevant provision reads: "Unless the treaty otherwise provides or it is otherwise agreed, a State or an international organization may

102121 Report, supra note 1, at 62 (guideline 6).

${ }^{11}$ Vienna Convention on the Law of Treaties, May 23, 1969, art. 26, 1155 UNTS 331, 8 ILM 679 (1969) [hereinafter VCLT].

122121 Report, supra note 1, at 63 (guideline 7).

${ }^{13}$ Id. at 63 (guideline 9, paras. 1 and 2).

${ }^{14}$ VCLT, supra note 11, art. 25(2). 
invoke other grounds for terminating provisional application, in which case it shall notify the other States or international organizations concerned." 15 This provision usefully recognizes what is probably understood in practice, which is that a state may terminate provisional application for any reason upon notice (and thus not solely in circumstances where it does not intend to become a party to the treaty), unless the agreement on provisional application provides otherwise. At the same time, a fourth paragraph was added indicating that such termination "does not affect any right, obligation or legal situation created through the execution of such provisional application prior to its termination."16

The annex to the Guide was originally envisaged as consisting of "model clauses," whereby the Commission would adopt specially-crafted texts that could be used by states and international organizations in future agreements. At second reading, however, it was decided that it was difficult to craft such clauses out of the context of the particular agreement for which the clause was being used. Consequently, the Commission opted instead to develop an annex containing examples of existing provisions from treaties and other instruments, by which states and international organizations have agreed on provisional application of a treaty. The examples, which are drawn from instruments such as the Arms Trade Treaty ${ }^{17}$ or the U.S.-Liberia agreement on suppressing weapons of mass destruction, ${ }^{18}$ are grouped into various categories designed to illuminate saliant aspects of an agreement on provisional application: the commencement of provisional application; ${ }^{19}$ the form of the agreement on provisional application (such as a side agreement or an exchange of diplomatic notes) ${ }^{20}$ the method by which a state or international organization may opt into or opt out of provisional application; ${ }^{21}$ the conditioning of provisional application by limitations derived from internal law (or from rules of international organizations); ${ }^{22}$ and the termination of provisional application. ${ }^{23}$

The Commission decided to recommend that the General Assembly take note of the Guide, encourage its widest possible dissemination, and commend it to the attention of States and international organizations. ${ }^{24}$ It also requested the Secretary-General to publish the practice of States and international organizations.

\section{PROTECTION OF THE ATMOSPHERE}

The Commission also completed the second reading of the topic protection of the atmosphere ${ }^{25}$ based on a sixth report by the special rapporteur, Shinya Murase (Japan), ${ }^{26}$ and on

${ }^{15} 2121$ Report, supra note 1, at 63 (guideline 9, para. 3).

${ }^{16} I d$. (guideline 9, para. 4).

${ }^{17}$ Arms Trade Treaty, Apr. 2, 2013, art. 23, 3013 UNTS, No. 52373 (not yet published).

${ }^{18}$ Agreement Concerning Cooperation to Suppress the Proliferation of Weapons of Mass Destruction, Their Delivery Systems, and Related Materials by Sea, Liberia-U.S., Feb. 11, 2004, art. 17, 2963 UNTS 23.

${ }^{19} 2121$ Report, supra note 1, at 64-70 (annex, sect. A).

${ }^{20} I d$. at 70-71 (annex, sect. B).

${ }^{21} I d$. at 71-72 (annex, sect. C).

${ }^{22} I d$. at $72-74$ (annex, sect. D).

${ }^{23} \mathrm{Id}$. at $74-78$ (annex, sect. E).

${ }^{24} I d$. at 61 , para. 49.

${ }^{25}$ For the text of the draft guidelines, see id. at 13-15; for the guidelines with commentary, see id. at 16-59.

${ }^{26}$ See International Law Commission, Sixth Report on the Protection of the Atmosphere, UN Doc. A/CN.4/736

(Feb. 11, 2020) (prepared by Special Rapporteur Shinya Murase). For discussion of prior work on this topic, see 
comments received from governments and international organizations regarding the text and commentary adopted at first reading in 2018. ${ }^{27}$ The outcome of this topic is a draft preamble and twelve draft guidelines with commentary.

In the draft preamble, the Commission decided to change the clause stating that "protection of the atmosphere from atmospheric degradation and atmospheric pollution is a pressing concern of the international community as a whole" to provide instead that "atmospheric degradation and atmospheric pollution are a common concern of humankind." 28 That change was prompted by some comments received from governments and by the use of such phrase in some instruments in the field of international environmental law, including the 2015 Paris Agreement on climate change. ${ }^{29}$ Concern about the expression being interpreted as having legal significance resulted in the Commission carefully explaining its meaning in the commentary, essentially characterizing the expression as simply identifying a factual situation (concern by states about an environmental problem prompting a desire for their cooperation) rather than as having any legally-operative effects (such as creating or entailing rights or obligations). The commentary states:

The phrase as used in this preambular paragraph reflects a concern of the entire international community that all may be affected by atmospheric pollution and atmospheric degradation, as defined in the draft guidelines. It is recalled that the expression has commonly been used in the field of environmental law, even though doctrine is divided on its scope, content and consequences. It is understood that the expression identifies a problem that requires cooperation from the entire international community, while at the same time that its inclusion does not create, as such, rights and obligations, and, in particular, that it does not entail erga omnes obligations in the context of the draft guidelines. ${ }^{30}$

Continuing concern that the draft guidelines not be regarded as a basis for interfering with carefully-negotiated, existing treaties or with complex future negotiations relating to the atmosphere resulted in the recrafting of the final draft preambular paragraph to read: "Recalling that the present draft guidelines were elaborated on the understanding that they were not intended to interfere with relevant political negotiations or to impose on current treaty regimes rules or principles not already contained therein." ${ }^{31}$ In this regard, it is noted that a proposal at second reading by the special rapporteur to include a new paragraph that failure of states to implement their obligations under international law relating to protection of the atmosphere "entails the responsibility of States" ${ }^{\prime 32}$ was not adopted.

Murphy, Sixty-Fifth Session, supra note 5, at 56-57; Murphy, Sixty-Sixth Session, supra note 5, at 139; Murphy, SixtySeventh Session, supra note 5, at 832-35; Murphy, Sixty-Eighth Session, supra note 5, at 729-30; Murphy, Sixty-Ninth Session, supra note 5, at 980-81; Murphy, Seventieth Session, supra note 5, at 96-97.

${ }^{27}$ Protection of the atmosphere: Comments and observations received from Governments and international organizations, UN Doc. A/CN.4/735 (Feb. 11, 2020).

282121 Report, supra note 1, at 13 (draft preamble, para 3).

${ }^{29}$ Paris Agreement, pmbl., para. 11, Dec. 12, 2015, 55 ILM 740 (2016).

302121 Report, supra note 1, at 18-19, para. (3) (commentary to draft preamble, para. 3).

${ }^{31} \mathrm{Id}$. at 13 (draft preamble, para. 8).

${ }^{32}$ Sixth Report, supra note 26 , at para. 87. 
The definition of "atmospheric pollution" in draft guideline 1 was altered so as to include the release into the atmosphere of not just substances, but also "energy," but the definition was simultaneously limited to encompass only releases contributing to "significant" deleterious effects extending beyond the state of origin that endanger human life and health, or the environment. ${ }^{33}$

The heart of the draft guidelines is likely draft guideline 3, which contains a heavily caveated "obligation to protect the atmosphere," left unchanged from the first reading: "States have the obligation to protect the atmosphere by exercising due diligence in taking appropriate measures, in accordance with applicable rules of international law, to prevent, reduce or control atmospheric pollution and atmospheric degradation." 34 The reason for the caveats is likely that such an obligation does not exist in any treaty, nor is it possible to say that widespread state practice in conjunction with opinio juris demonstrates the existence of such a rule in customary international law. ${ }^{35}$ Arguably, the phrase "in accordance with applicable rules of international law" means that the draft guideline simply restates the obligation of states parties to abide by their treaty commitments.

The Commission decided to recommend that the General Assembly take note of the draft guidelines, annex them to a resolution, ensure their widest possible dissemination, and commend them to "the attention of States, international organizations and all who may be called upon to deal with the subject." 36

\section{OTHER Topics AdDRESSED DuRING THE SEVENTIETH SESSION}

\section{Immunity of State Officials from Foreign Criminal Jurisdiction}

The topic on immunity of state officials from foreign criminal jurisdiction remains the longest one on the current program of work of the Commission. ${ }^{37}$ Prior to the present session, the Commission had adopted several draft articles: draft article 1 (scope); draft article 2 (definitions) (adopted in part); draft article 3 (persons enjoying immunity ratione personae); draft article 4 (scope of immunity ratione personae); draft article 5 (persons enjoying immunity ratione materiae); draft article 6 (scope of immunity ratione materiae); draft article 7 (crimes under

332121 Report, supra note 1, at 13 (draft guideline 1(b)).

${ }^{34} \mathrm{Id}$. at 14 (draft guideline 3) (emphasis added).

${ }^{35}$ While commentary asserts that draft guideline 3 "restates the obligation to protect the atmosphere," id., at 30, para (1), the commentary does not point to any such obligation in existing treaties, nor analyzes state practice and opinio juris in support of it. The commentary points to a "genesis" of such an obligation in the Trail Smelter arbitration and Stockholm Declaration Principle 21, id., at 30-31, para (3), but those sources do not concern damage to the atmosphere as such, but damage by one state to the environment of another state (or to areas beyond national jurisdiction). The commentary also asserts that the phrase "prevent, reduce or control" draws upon formulations contained in five conventions, $i d$., at 32, para (7), n. 80-81 but none of those conventions refers to an "obligation to protect the atmosphere"; rather, they regulate in specific ways particular types of emissions into the atmosphere because those emissions result in specific types of harm to humans or the environment.

${ }^{36}$ Id. at 12, para. 37.

${ }^{37}$ For discussion of prior work on this topic, see Murphy, Sixty-Fourth Session, supra note 5, 169-71; Murphy, Sixty-Fifth Session, supra note 5, at 41-48; Murphy, Sixty-Sixth Session, supra note 5, at 139-40; Murphy, SixtySeventh Session, supra note 5, at 842; Murphy, Sixty-Eighth Session, supra note 5, at 732-42; Murphy, Sixty-Ninth Session, supra note 5, at 981-88; Murphy, Seventieth Session, supra note 5, at 106; Murphy, Seventy-First Session, supra note 5, at 81-82. 
international law in respect of which immunity ratione materiae shall not apply); and an annex (list of treaties referred to in draft article 7, paragraph 2). ${ }^{38}$ While there was hope that the Commission might complete the first reading of this topic at the present session, it did not, and hence will seek to do so at the 73rd session.

At the outset of the session, numerous draft articles remained pending in the drafting committee. Work was completed on several of those draft articles, which (along with commentary) were provisionally adopted by the Commission. In addition to draft article 8 ante, ${ }^{39}$ the Commission adopted five draft articles setting forth procedures to be followed by the forum state and the state of the official, specifically draft 8 (examination of immunity by the forum state); draft article 9 (notification of the state of the official); draft article 10 (invocation of immunity); draft article 11 (waiver of immunity); and draft article 12 (requests for information). ${ }^{40}$ The general thrust of these draft articles is to require the forum state to examine at an early stage whether an issue of immunity has arisen, and to notify the state of the official before the forum state initiates criminal proceedings or takes coercive measures against the official. The state of the official may then either invoke or waive the immunity of the official. Either state may request information from the other state to assist in such steps.

These draft articles are the prelude to an anticipated draft article 13 on the forum state's "determination of immunity," which is to be made in light of the reaction (if any) of the state of the official. Among other things, such determination might be conditioned in various ways. For example, in the absence of a waiver and at least in the context of applying draft article 7, draft article 13 might require - before denying immunity - that the official be present in the forum state, that the evidence of the official committing the alleged offence be fully conclusive, and that the determination be taken at the highest possible level of governmental or prosecutorial authority. ${ }^{41}$

Work was not completed in the drafting committee on certain other pending draft articles, specifically: definitions in draft article 2 for "criminal jurisdiction," "immunity from foreign criminal jurisdiction," "immunity ratione personae," and "immunity ratione materiae"; draft article 14 (transfer of proceedings to the State of the official); draft article 15 (consultations); and draft article 16 (fair and impartial treatment of the official). Draft article 14 may also include a pertinent safeguard, if it requires transfer of the official from the forum state to the state of the official whenever the latter is able and willing to submit the matter to prosecution before its own courts (or if the two states agree, to a competent international criminal court).

${ }^{38}$ See 2121 Report, supra note 1, at 122-23, 125 (draft articles 1-7 and draft annex).

39 This draft article was adopted by the drafting committee during the 71st session, see Murphy, Seventy-First Session, supra note 5, at 81-82, but was only adopted by the Commission at the 72nd session. See 2121 Report, supra note 1 , at 123 (draft article 8 ante).

${ }^{40}$ See 2121 Report, supra note 1, at 124-25 (draft articles 8-12); for the commentary to these draft articles, see id. at $126-51$.

${ }^{41}$ See Report of the International Law Commission on the Work of Its Seventieth Session, UN GAOR, 73rd Sess., Supp. No. 10, at 292, para. 323, UN Doc. A/73/10 (Sept. 3, 2018). 
At the present session, the Commission also had before it the eighth report on the topic submitted by its second special rapporteur for this topic, Concepción Escobar Hernández (Spain). ${ }^{42}$ In the report, the special rapporteur proposed a means for settling disputes between the forum state and the state of the official. Specifically, draft article 17 would provide for consultations between the two states and, if the dispute remains unresolved, for negotiations; if it still remained unresolved, either party could "suggest" reference of the dispute to arbitration or to the International Court of Justice (ICJ). ${ }^{43}$ The report also examined the relationship between the immunity of State officials from foreign criminal jurisdiction and international criminal tribunals, ${ }^{44}$ and in particular considered the judgment of the Appeals Chamber of the International Criminal Court in the Jordan Referral re Al-Bashir case. ${ }^{45}$ Among other things, the special rapporteur noted that "the assessment made of the judgment from different academic positions and by some States and the Court itself has not been kind." 46 Ultimately, the special rapporteur only proposed a draft article 18 that reads: "The present draft articles are without prejudice to the rules governing the functioning of international criminal tribunals." 47 After the report was debated in the Commission, both draft articles were referred to the drafting committee, where they remain pending.

\section{Succession of States in respect of State Responsibility}

In 2016, the Commission moved the topic of succession of states in respect of state responsibility onto the current program of work and appointed Pavel Šturma (Czech Republic) as special rapporteur. Generally speaking, this topic is analyzing the rules on state responsibility applicable to the rights and obligations of a predecessor state, a successor state, and third states, in situations where a succession of states occurs. The Commission in 2019 provisionally adopted draft article 1 (scope), draft article 2 (use of terms), and draft article 5 (cases of succession covered), ${ }^{48}$ and in 2021 provisionally adopted draft article 7 (acts having a continuing character), draft article 8 (attribution of conduct of an insurrectional or other movement), and draft article 9 (cases of succession of states when the predecessor state continues to exist). ${ }^{49}$ Draft article 3 (relevance of agreements to succession of states in respect of state responsibility) and draft article 4 (unilateral declaration by a successor state) remain pending in the drafting committee. ${ }^{50}$

A continuing feature of the work on this topic is the divide between members who favor recognizing succession by successor states to the responsibility originally incurred by a predecessor state (an "automatic succession" rule), and those members who favor recognizing that there is no such obligation (a "blank slate" rule). Resolving that divide has proven difficult in the

${ }^{42}$ International Law Commission, Eighth Report on Immunity of State Officials from Foreign Criminal Jurisdiction, UN Doc. A/CN.4/739 (Feb. 28, 2020) (prepared by Special Rapporteur Concepción Escobar Hernández) [hereinafter Eighth Report on Immunity of State Officials from Foreign Criminal Jurisdiction].

${ }^{43} I d$. at para. 54.

${ }^{44} I d$. at paras. $20-31$.

${ }^{45}$ Situation in Darfur, Sudan, in the Case of the Prosecutor v. Omar Hassan Ahmad Al-Bashir, Judgment in the Jordan Referral re Al-Bashir Appeal, Judgment of the Appeals Chamber, ICC-02/05-01/09-397-Corr (May 6, 2019).

${ }^{46}$ Eighth Report on Immunity of State Officials from Foreign Criminal Jurisdiction, supra note 42, at para. 23.

${ }^{47} I d$. at para. 32.

${ }^{48} 2121$ Report, supra note 1, at 164 (draft articles 1-2, 5).

${ }^{49} \mathrm{Id}$. at 165 (draft articles 7-9). For the commentary to these draft articles, see id. at 165-69.

${ }^{50}$ For discussion of prior work on this topic, see Murphy, Sixty-Ninth Session, supra note 5, at 990-92; Murphy, Seventieth Session, supra note 5, 104-06; Murphy, Seventy-First Session, supra note 5, at 78-81. 
face of the relatively sparse and sometimes conflicting state practice, often involving arguably sui generis agreements among the states concerned. In that light, at the present session the drafting committee considered three draft articles that remained pending from the 71 st session relating to obligations arising in three types of succession scenarios: the uniting of states (e.g., the United Arab Republic in 1958); the incorporation of one state in another (e.g., the unification of Germany in 1990); and dissolution of a state (e.g., the former Yugoslavia beginning in 1990). For each scenario, the drafting committee ultimately adopted neither an automatic succession rule nor a blank slate rule, but instead a rule that the states concerned "shall agree on how to address the injury." Such agreement presumably might involve full, partial or no reparation. ${ }^{51}$

Specifically, draft article 10 on "Uniting of States" provides: "When two or more States unite and so form one successor State, and an internationally wrongful act has been committed by any of the predecessor States, the injured State and the successor State shall agree on how to address the injury." 52 Draft article 10 bis, on "Incorporation of a State into another State," provides in paragraph 1: "When an internationally wrongful act has been committed by a State prior to its incorporation into another State which continues to exist, the injured State and the incorporating State shall agree on how to address the injury." 53 Draft article 11 on "Dissolution of a State" provides:

When a State that has committed an internationally wrongful act dissolves and ceases to exist and the parts of the territory of the predecessor State form two or more successor States, the injured State and the relevant successor State or States shall agree on how to address the injury arising from the internationally wrongful act. They should take into account any territorial link, any benefit derived, any equitable apportionment, and all other relevant circumstances. ${ }^{54}$

At the present session, the Commission also had before it the fourth report of the special rapporteur, which focused on questions relating to the impact of succession of states on breaches

\footnotetext{
${ }^{51}$ See Succession of States in respect of State responsibility, Statement of the Chair of the Drafting Committee Ms. Patrícia Galvão Teles (July 28, 2021), at https://legal.un.org/ilc/documentation/english/statements/2021_dc_chair_statement_sosr.pdf. For example, with respect to the formulation as used in draft article 10, the chair of the drafting committee maintained that the formulation "shall agree on how to address the injury"

does not articulate a "clean slate" rule or an automatic succession rule. Instead, it is intended to encourage States to seek a solution to questions of international responsibility in situations of a merger between States. The formulation of the wording is meant to be sufficiently flexible to give States the freedom to choose the modalities of the agreement. Such flexibility could even result in agreement between the injured State and the successor State that it was not possible to address the injury.
}

Id. at 5.

${ }^{52}$ Succession of States in respect of State responsibility: Text of draft articles 10, 10 bis and 11 provisionally adopted by the Drafting Committee at the seventy-second session, UN Doc. A/CN.4/L.954 (July 19, 2021) (draft article 10).

${ }^{53} \mathrm{Id}$. (draft article 10 bis(1)). A second paragraph simply confirms that when "an internationally wrongful act has been committed by a State prior to incorporating another State, the responsibility of the State that committed the wrongful act is not affected by such incorporation." Id. (draft article 10 bis(2)).

${ }^{54} I d$. (draft article 11). 
of a composite character, on reparation, and on assurances of non-repetition. ${ }^{55}$ Those draft articles were referred to,${ }^{56}$ but remain pending in, the drafting committee. To assist in its work, the Commission requested information from states on their treaties, national laws, and court decisions relating to this topic. ${ }^{57}$

\section{General Principles of Law}

In 2018, the Commission moved the topic of general principles of law onto the current program of work and appointed Marcelo Vázquez-Bermúdez (Ecuador) as special rapporteur. ${ }^{58}$ Generally speaking, this topic is analyzing the third source of international law, as reflected in ICJ Statute article 38(1)(c): "the general principles of law recognized by civilized nations." ${ }^{59}$ At the request of the Commission, its Secretariat produced a detailed memorandum surveying the case law of inter-state arbitral tribunals and international criminal courts and tribunals of a universal character, as well as treaties, which are relevant to work on the topic. ${ }^{60}$

At the 71st session, the drafting committee had adopted the English-language text of draft conclusion 1 on the scope of the topic, which states that the topic "concerns general principles of law as a source of international law." ${ }^{61}$ At the $72 \mathrm{nd}$ session, the Commission adopted draft conclusion 1 (in all languages), having resolved an issue with the French and Spanish texts. ${ }^{62}$

The Commission also adopted draft conclusion 2, entitled "Recognition," which provides: "For a general principle of law to exist, it must be recognized by the community of nations." 63 Two important aspects of this draft conclusion merit attention. First, as indicated by the commentary, it reaffirms that recognition is "the essential condition for the emergence of a general principle of law." "64 Anyone called upon to apply such a general principle of law must "examine all the available evidence showing that its recognition has taken place," with the specific and objective criteria for doing so to be developed in the subsequent draft conclusions. ${ }^{65}$ Second, the draft conclusion drops the word "civilized" from the language that appears in the ICJ's Statute, and replaces it instead with "the community of". The commentary to this draft conclusion explains:

(3) Draft conclusion 2 employs the term "community of nations" as a substitute for the term "civilized nations" found in Article 38, paragraph 1 (c), of the Statute of the

55 See International Law Commission, Fourth Report on Succession of States in Respect of State Responsibility, UN Doc. A/CN.4/743 (Mar. 27, 2020) (prepared by Special Rapporteur Pavel Šturma).

562121 Report, supra note 1, at 154, para. 123.

${ }^{57}$ Id. at 9, para. 25.

${ }^{58}$ For discussion of prior work on this topic, see Murphy, Seventy-First Session, supra note 5, at 82-84.

${ }^{59}$ Statute of the International Court of Justice, art. 38(1)(c).

${ }^{60}$ General principles of law: Memorandum by the Secretariat, UN Doc. A/CN.4/742 (May 12, 2020).

${ }^{61}$ See 2121 Report, supra note 1, at 182 (draft conclusion 1).

62 There was initially disagreement within the Commission on the French and Spanish texts. Whereas the ICJ Statute refers to "principes généraux de droit" and "principios generales de derecho", the terms "du droit" and "del derecho" have also been used in some more recent texts identifying this source of international law. The Commission decided to use the latter terms for the purposes of this topic, but it was understood that doing so did not imply any difference with the substance of ICJ Statute Article 38(1)(c). See id. at 183, n. 426.

${ }^{63} \mathrm{Id}$. at 182 (draft conclusion 2).

${ }^{64} I d$. at 183, para. (2) (commentary to draft conclusion 2).

${ }^{65} I d$. 
International Court of Justice, because the latter term is anachronistic. The term "community of nations" is found in article 15, paragraph 2, of the International Covenant on Civil and Political Rights, a treaty to which 173 States are parties and which is thus widely accepted. The term used in the authentic languages of the Covenant is replicated in the different language versions of draft conclusion 2.... By employing this formulation, the draft conclusion aims to stress that all nations participate equally, without any kind of distinction, in the formation of general principles of law, in accordance with the principle of sovereign equality set out in Article 2, paragraph 1, of the Charter of the United Nations.

(4) The use of the term "community of nations" is not intended to modify the scope or content of Article 38, paragraph $1(c)$, of the Statute of the International Court of Justice. In particular, the term does not seek to suggest that there is a need for a unified or collective recognition of a general principle of law, nor does it suggest that general principles of law can only arise within the international legal system. Furthermore, the term "community of nations" should not be confused with the term "international community of States as a whole" found in article 53 of the Vienna Convention on the Law of Treaties, relating to peremptory norms of general international law (jus cogens). ${ }^{66}$

Work in the drafting committee on draft conclusion 3 was suspended due to the continuing disagreement among members as to whether "general principles of law" comprise only those principles derived from national legal systems, or may also include those formed within the international legal system. ${ }^{67}$ The special rapporteur's proposal for draft conclusion 3 recognizes both possibilities $^{68}$ and so was set aside for the time being.

At the present session, the Commission had before it the second report of the special rapporteur, in which he proposed several new draft conclusions. ${ }^{69}$ The drafting committee completed work on and the Commission adopted draft conclusion 4, entitled "Identification of general principles of law derived from national legal systems." It provides that to "determine the existence and content of a general principle of law derived from national legal systems, it is necessary to ascertain: (a) the existence of a principle common to the various legal systems of the world; and (b) its transposition to the international legal system."70 The commentary indicates that the first part of this two-step analysis is "essentially inductive"; one must show that a legal principle is found in the various legal systems of the world. ${ }^{71}$ The expression "various legal systems of the world" is, according to the commentary, "an inclusive and broad expression, covering the variety and diversity of the legal systems of the world." 72 The second part refers to the determination that a principle common to the various legal systems of the world "can be applied

${ }^{66} I d$. at 184 , paras. (3)-(4) (commentary to draft conclusion 2).

${ }^{67}$ See id. at paras. 210-15 (summary of debate at the 72nd session on this issue); see also Murphy, SeventyFirst Session, supra note 5, at 82-84.

${ }^{68}$ See International Law Commission, First Report on General Principles of Law, UN Doc. A/CN.4/732, at 6773 (Apr. 5, 2019) (prepared by Special Rapporteur Marcelo Vázquez-Bermúdez).

${ }^{69}$ International Law Commission, Second Report on General Principles of Law, UN Doc. A/CN.4/741 (Apr. 9, 2021) (prepared by Special Rapporteur Marcelo Vázquez-Bermúdez) [hereinafter Second Report on General Principles of Law].

${ }^{70}$ See 2121 Report, supra note 1, at 182 (draft conclusion 4).

712121 Report, supra note 1, at 185, para. (3) (commentary to draft conclusion 4).

${ }^{72} I d$. 
in the international legal system," a recognition that such a principle (or some elements of a principle) "may not be suitable" for such application. ${ }^{73}$

The drafting committee also adopted draft conclusion 5, but it has not yet been adopted by the Commission. Entitled "Determination of the existence of a principle common to the various legal systems of the world," draft conclusion 5 reads:

1. To determine the existence of a principle common to the various legal systems of the world, a comparative analysis of national legal systems is required.

2. The comparative analysis must be wide and representative, including the different regions of the world.

3. The comparative analysis includes an assessment of national laws and decisions of national courts, and other relevant materials. ${ }^{74}$

The special rapporteur's other proposals that remain pending in the drafting committee are: draft conclusion 6 (ascertainment of transposition to the international legal system); draft conclusion 7 (identification of general principles of law formed within the international legal system; draft conclusion 8 (decisions of courts and tribunals); and draft conclusion 9 (teachings). ${ }^{75}$ Of these, draft conclusion 7 may be the most interesting - and the most controversial given the disagreement among the members indicated above. The proposal reads:

To determine the existence and content of a general principle of law formed within the international legal system, it is necessary to ascertain that:

(a) a principle is widely recognized in treaties and other international instruments;

(b) a principle underlies general rules of conventional or customary international law; or

(c) a principle is inherent in the basic features and fundamental requirements of the international legal system. ${ }^{76}$

\section{Sea-Level Rise in Relation to International Law}

At the seventy-first session, the Commission placed on its current program of work the topic of sea-level rise in relation to international law, to be addressed in the context of a study group, which is open to all members. ${ }^{77}$ The topic was proposed by a group of ILC members who are serving as co-chairs of the study group: Bogdan Aurescu (Romania); Yacouba Cissé (Côte

\footnotetext{
${ }^{73} I d$. at 185 , paras. (4)-(7) (commentary to draft conclusion 4).

${ }^{74}$ General principles of law: Addendum: Text and title of draft conclusion 5, provisionally adopted by the Drafting Committee, UN Doc. A/CN.4/L.955/Add.1 (July 29, 2021).

${ }^{75}$ Second Report, supra note 69, at 57-58.

${ }^{76} \mathrm{Id}$. at 57 (proposed draft conclusion 7).

${ }^{77}$ For discussion of prior consideration of this topic, see Murphy, Seventieth Session, supra note 5, 107-08; Murphy, Seventy-First Session, supra note 5, at 84-85.
} 
d'Ivoire); Patricia Galvão Teles (Portugal); Nilüfer Oral (Turkey); and Juan José Ruda Santolaria (Peru).

For the present session, it was decided that the study group would focus on issues relating to the law of the sea. Consequently, two of the co-chairs (Aurescu and Oral) prepared a "first issues paper", ${ }^{78}$ which served as the basis for the study group's work. A central aspect of the paper's analysis concerned whether the baselines of a coastal state should move when sea-level rise occurs ("ambulatory baselines") or whether they may remain fixed ("permanent baselines"). The two cochairs concluded that "nothing prevents Member States from depositing notifications, in accordance with the [UN Convention on the Law of the Sea], regarding the baselines and outer limits of maritime zones measured from the baselines and, after the negative effects of sea-level rise occur, to stop updating these notifications in order to preserve their entitlements." 79 The underlying reason for such a conclusion appears to be equity owed to the coastal state, given that "the landward movement of the baseline and the outer limits of maritime zones would result in the coastal State losing sovereignty and jurisdiction rights over regulating the navigation of third States and their nationals." ${ }^{\prime 0}$ Moreover, with respect to maritime boundaries, the co-chairs suggested that "in order to preserve legal stability, security, certainty and predictability, it is necessary to preserve existing maritime delimitations, either effected by agreement or by adjudication, notwithstanding the coastal changes produced by sea-level rise. ${ }^{\prime 81}$ For similar reasons, the co-chairs implied that fully-entitled islands, rocks and low-tide elevations should not be reclassified based on sea-level rise, given that " $[\mathrm{r}]$ ecent international jurisprudence...lends support to the need to maintain the stability of maritime entitlements." 82 A third co-chair (Cissé) made a presentation at the session on the practice of African states, in which he concluded that such practice was diverse and that "it was not possible to infer the existence of opinio juris in favour or against permanent or ambulatory baselines or maritime boundaries." 83

The study group debated the report by the two co-chairs. While the meetings of the study group are not public, the discussions are summarized in the Commission's annual report. ${ }^{84}$ Some concerns were expressed that the co-chairs' paper had been interpreted outside the Commission as already reflecting the Commission's views, when it was actually just the product of two members. ${ }^{85}$ While some members supported the co-chairs' analysis, other members expressed doubts about the conclusions reached, and called for more rigorous study. ${ }^{86}$ Among other things, it was noted that: baselines are not established by coastal state charts or lists, but instead are established by the rules of the law of the sea; ${ }^{87}$ the normal baseline under the law of the sea is the

${ }^{78}$ Sea-level rise in relation to international law: First issues paper by Bogdan Aurescu and Nilüfer Oral, CoChairs of the Study Group on sea-level rise in relation to international law, UN Doc. A/CN.4/740 (Feb. 28, 2020) [hereinafter "First issues paper on sea-level rise in relation to international law"]. For several corrections to the paper, see Corrigendum, UN Doc. A/CN.4/740/Corr.1 (Aug. 3, 2021).

${ }^{79}$ First issues paper on sea-level rise in relation to international law, supra note 78, at 41, para. 104(f).

${ }^{80} \mathrm{Id}$. at 67 , para. $190(\mathrm{a})$.

${ }^{81}$ Id. at 54, para. 141(b).

${ }^{82} \mathrm{Id}$. at 79-80, para. 218.

${ }^{83} 2121$ Report, supra note 1, at paras. 259-61.

${ }^{84} \mathrm{Id}$. at 187-201, paras. 252-95.

${ }^{85} \mathrm{Id}$. at para. 191, para. 265.

${ }^{86} \mathrm{Id}$. at 266.

${ }^{87}$ Id. at 193, para. 270. 
low-water line along the coast, ${ }^{88}$ which is inherently ambulatory and not fixed; ${ }^{89}$ the charts or lists indicated in article 16 of the UN Convention on the Law of the Sea only concern straight baselines or closing lines, not other baselines; ${ }^{90}$ even then, the straight baselines or closing lines shown on such charts or lists are to be "in accordance with" certain rules, ${ }^{91}$ such as the requirement that straight baselines "not depart to any appreciable extent from the general direction of the coast"; 92 the interests of not just coastal states but of other states must also be considered, ${ }^{93}$ such as with respect to navigational, overflight and other freedoms; agreements and judicial decisions on maritime boundaries only bind the parties to such agreements or cases, and cannot affect the rights of third states with respect to maritime areas where a coastal state no longer has sovereignty or sovereign rights $;{ }^{94}$ any new rule based specifically on change of a coastline due to sea-level rise would need to consider that coastlines change due to many other factors (e.g., storms, waves, wind, or rainfall, all possibly aggravated by climate change), such that a basis for identifying a change that is unique to sea-level rise would be needed; 95 and the maintenance of "stability" might entail following, rather than abandoning, the settled rules of the law of the sea, as a departure from them could result in states claiming unexpected maritime entitlements that have no relation to physical reality. ${ }^{96}$

During the seventy-third session in 2022, the study group intends to focus on issues related to statehood and to the protection of persons affected by sea-level rise, rather than on issues relating to the law of the sea. ${ }^{97}$ Since its work will likely not be completed in this quinquennium, the study group is expected to be reconvened during the next quinquennium. To assist in the study group's work, the Commission has requested information from states on their practice, treaties, national laws, and court decisions relating to this topic. ${ }^{98}$

\section{NEW TOPIC FOR THE LONG-TERM WORK PROGRAM}

During the seventy-second session, the Commission placed a new topic on its long-term work program, which concerns subsidiary means for the determination of rules of international law. ${ }^{99}$ Addition of this topic to the long-term work program may be seen in the context of the Commission in recent years addressing various matters related to the sources of international law, notably by its topics on: identification of customary international law (completed in 2018); subsequent agreements and subsequent practice in relation to the interpretation of treaties (completed in 2018); provisional application of treaties (completed in 2021); peremptory norms of

${ }^{88}$ See, e.g., United Nations Convention on the Law of the Sea, opened for signature Dec. 10, 1982, 1833 UNTS 396 (entered into force Nov. 16, 1994), art. 5.

892121 Report, supra note 1, at 193, para. 271.

902121 Report, supra note 1, at 193, para. 270.

${ }^{91}$ Id.; see, e.g., United Nations Convention on the Law of the Sea, supra note 88, art. 16 (referring to the baselines for measuring the breadth of the territorial sea "determined in accordance with articles 7, 9 and 10").

92 See United Nations Convention on the Law of the Sea, supra note 88, art. 7(3).

932121 Report, supra note 1, at 194, at para. 277.

${ }^{94}$ Id. at 196, para. 281.

${ }^{9} I d$. at 190, para. 263.

${ }^{96} I d$. at 191, 193-94, paras. 266, 273.

${ }^{97}$ Id. at 201, para. 296.

${ }^{98}$ Id. at 9-10, paras. 26-28.

992121 Report, supra note 1, at 202, para. 302. 
general international law (jus cogens) (likely to be completed in 2022); and general principles of law (ongoing).

It is recalled that ICJ Statute Article 38(1)(d) provides that, in resolving disputes, the Court shall apply, "subject to the provisions of Article 59, judicial decisions and the teachings of the most highly qualified publicists of the various nations, as subsidiary means for the determination of rules of law." ${ }^{100}$ According to the syllabus, prepared by Charles Jalloh (Sierra Leone), ${ }^{101}$

there are aspects of these subsidiary means and their interaction and relationship to the sources that are uncertain, confusing, and arguably even unsettled. Consequently, in order not to leave a gap in the clarity, predictability and uniformity of international law, it is proposed that the Commission consider completing its systematic study of Article 38(1) by also examining the subsidiary means for the determination of rules of international law listed in sub-paragraph $(\mathrm{d}) \ldots{ }^{102}$

The degree and depth of such uncertainties are unclear, though the syllabus maintains that there are differences of views as to whether judicial decisions are solely a vehicle for finding international law (as opposed to being a direct source of international law), ${ }^{103}$ as well as questions as to the status of national court (as opposed to international court) decisions ${ }^{104}$ and the different roles national court decisions can play across different sources of law. ${ }^{105}$ In any event, the Commission will now await reactions to this proposed topic by states and others to gauge the support for or opposition to it.

\section{ELECTIONS}

During the seventy-second session, the Commission held an election to fill a "casual vacancy," meaning a vacancy arising during the course of the Commission's quinquennium. In such a situation, the Commission's Statute provides that, rather than an election being held at the UN General Assembly, the Commission itself shall fill the vacancy. ${ }^{106}$ The vacancy was occasioned by the resignation from the Commission of Georg Nolte (Germany), who had been elected as an ICJ judge. A single candidate was advanced for election to fill this vacancy, Mathias Forteau (France), who had previously been a member of the Commission from 2012 to 2016. He was duly elected by the Commission on April 29 to serve for the remainder of the current quinquennium. ${ }^{107}$

The current members of the Commission originally were to serve terms that would expire in 2021. However, after the COVID-19 pandemic precluded the Commission from meeting in

${ }^{100}$ Statute of the International Court of Justice, art. 38(1)(d). Article 59 of the Statute provides that the "decision of the Court has no binding force except between the parties and in respect of that particular case."

1012121 Report, supra note 1, at 210, Annex.

${ }^{102} I d$. at 211 , para. 6.

${ }^{103} I d$. at 213, para. 13.

${ }^{104} I d$., para. 14.

${ }^{105} I d$., at 213-14, paras. 15-16.

${ }^{106}$ See the Statute of the International Law Commission, UN Doc. A/RES/174(II), annex, art. 11 (Nov. 21, 1947).

1072121 Report, supra note 1, at 2, para. 3. 
2020, the General Assembly voted to extend the current members' term by one year, so as to end in 2022. ${ }^{108}$ Even so, the Secretary-General decided to move forward with election of the next Commission on the original schedule, such that the members of the next Commission will be elected in November 2021, but will not commence their five-year terms until January 2023. ${ }^{109}$ The candidate nominated by the United States is Evelyn Aswad, a former attorney at the U.S. Department of State Office of the Legal Adviser, and professor of international law at the University of Oklahoma College of Law.

${ }^{108}$ See Murphy, Effects of the COVID-19 Pandemic, supra note 2.

${ }^{109}$ For information on the 2021 election, including the slate of candidates, see 2021 Election of the International Law Commission (updated July 16, 2021), https://legal.un.org/ilc/elections/2021election.shtml. 